\title{
NILAI SOSIO-RELIGIUS MASYARAKAT DESA: Studi Interaksi Antarumat Beragama di Yogyakarta
}

\author{
Muhammad Taufik \\ nuraenitaufik@yahoo.com \\ UIN Sunan Kalijaga Yogyakarta
}

\begin{abstract}
This paper is the result of a field research that tries to trace the dynamics of rural communities related to interactions among religious people at Banguntapan Village, Yogyakarta. This research is appealing because village communities are still considered low and marginal class society; nevertheless in reality, they have local wisdom. The people of Banguntapan Village live in harmony, mutual cooperation -gotong royong- and are far from materialistic and luxurious life. This simple life creates their personalities that always respect each other, albeit different in religions, customs, and habits, which are apparent in the implementation of their socioreligious values they have embraced so far. This research uses a qualitative method. This method is chosen because it emphasizes on the depth of value. It tries to answer how the choice of action is interpreted and given a certain meaning. The results of this study found that the religious conditions in Banguntapan village run well despite the potentials for friction. However, it can still be minimized with the spirit of togetherness. The people are so heterogeneous; almost all ethnic groups from Sabang to Merauke are living there. The original community of Banguntapan, in this case the Javanese, has an inclusive attitude towards the migrants from outside Banguntapan. The community is known to be open to migrant from any place, which is important to adapt and appreciate the Javanese tradition that is full of cultural manners. The socio-religious values in the interaction pattern among the people of Banguntapan Village community are always in the context of mutual relationship and mutual influence with other people in order to meet their needs and sustain their life. In fact, they assume that they bave a meaning if there is another buman being with whom they could interact. Social interaction that they understand is a form of socio-cultural dynamics that exist in the life of society.
\end{abstract}

Keywords: Interaction, Social-religious, Religious people. 


\begin{abstract}
Abstrak: Tulisan ini merupakan hasil penelitian lapangan yang mencoba menelusuri dinamika masyarakat desa terkait dengan interaksi antar umat beragama yang lokasinya adalab Desa Banguntapan, Kecamatan Banguntapan, Kabupaten Bantul, Daerah Istimewa Yogyakarta. Penelitian ini menarik dilakukan karena masyarakat desa masib dianggap masyarakat kelas rendah dan marjinal. Namun kenyatannya memiliki kearifan lokal, yaitu salab satunya masyarakat Desa Banguntapan yang pada dasarnya mereka bidup rukun, gotong royong dan jauh dari kehidupan matrealistik dan mewah. Kehidupan yang sederhana ini menciptakan kepribadian mereka untuk selalu saling menghargai, meskipun berbeda agama dan kebiasaan, yang tampak dalam implementasi nilai sosio-religius yang mereka anut selama ini. Penelitian ini akan menggunakan metode kualitatif. Metode ini dipilib karena menekankan pada kedalaman nilai. Dengan metode ini akan mencoba menjawab bagaimana piliban tindakan untuk. dimaknai dan diberi arti tertentu. Hasil dari penelitian ini ditemukan babwa kondisi keberagamaan di Desa Banguntapan berjalan dengan baik walaupun ada potensi untuk terjadinya gesekan-gesekan tapi sejaub ini masih bisa diminimalisir dengan semangat kebersamaan. Masyarakatnya memang heterogen, hampir semua suku bangsa Indonesia dari Sabang sampai Merauke ada di sini. Masyarakat asli Banguntapan yang dalam hal ini orang Jawa mempunyai sikap inklusif terhadap pendatang dari luar Banguntapan. Masyarakatnya dikenal terbuka dengan kaum pendatang dari mana saja, yang penting bisa beradaptasi dan menghargai tradisi masyarakat Jawa yang penuh dengan budaya tatakrama. Nilai sosio-religius dalam pola interaksi antar umat beragama Masyarakat Desa Banguntapan senantiasa dalam konteks hubungan dan pengarub timbal balik dengan masyarakat yang lain dalam rangka memenuhi kebutuban dan mempertahankan kehidupannya.
\end{abstract}

Kata kunci: Interaksi, Sosio-Religius, Masyarakat Religius

\title{
Pendahuluan
}

Masyarakat desa dalam struktur sosial masyarakat Indonesia termasuk kategori "strata sosial rendah", kategorisasi ini disebabkan oleh marginalisasi citra masyarakat desa yang selama ini disebut sebagai kelompok masyarakat miskin, terbelakang, udik, dekil, kotor berlumpur. " "Pencitraan negatif" ini disebabkan oleh sentralisasi sistem tata kelola pemerintahan pada masa Orde Baru, lebih-lebih tidak adanya pemerataan pembangunan, dimana pada saat itu pemerintah lebih mengutamakan pembangunan kota sehingga menjadikan desa

1J. A Noertjahyo, Dari ladang sampai kabinet: menggugat nasib petani (Jakarta: Penerbit Buku Kompas, 2005), 19.

50 Khazanah, Vol. 16 (1), 2018 
sebagai kantong-kantong kemiskinan dan gambaran keterbelakangan, tidak salah bila ada gelombang urbanisasi yang sangat besar yang menyebabkan desa ditinggalkan dan orang berduyun-duyun pergi ke kota dengan berbagai alasan dan impian besar untuk merubah hidup agar lebih baik.

Sebagai masyarakat yang berstatus "sosial rendah" tersebut, biasanya masyarakat desa ini hidup di kampungkampung yang memiliki lahan pertanian. Lahan ini menjadi sumber kehidupan mereka. Namun demikian, meskipun masyarakat desa ini dimarginalkan secara politis dan ekonomis serta terbelakang dari masyarakat kota, mereka memiliki khazanah yang tidak ternilai dan masih terpendam, yakni beragam kearifan lokal yang selalu dilestarikan sejak nenek moyang mereka.

Keyakinan deskriptif orang Jawa sangat terasa bila dikaitkan dengan keyakinan pencapaian ketenangan batin, pandangan dunia yang semakin harmonis, cocok dan sreg. Jadi, bila kita membicarakan masalah pandangan dunia Jawa, tidak akan menjumpai orang yang hanya membicarakan fenomena kehidupan yang lain, termasuk sarana menghadapi masalahmasalah kehidupan (menanam padi, panen, keluarga, budaya, seni, mistik, dan doa selamatan). ${ }^{2}$

Salah satu kearifan lokal masyarakat desa di Jawa pada dasarnya adalah hidup rukun, gotong royong dan jauh dari kehidupan materialistik, mewah dan glamour. Kehidupan yang sederhana ini mencetak kepribadian mereka untuk selalu saling menghargai satu sama lain, meskipun berbeda agama dan kebiasaan, tidak menghalangi mereka untuk saling menghormati. Inilah salah satu khazanah yang tidak ternilai yang tertanam dalam diri masyarakat desa yang selama ini dianggap sebagai "strata sosial paling rendah" tersebut.

Kehidupan masyarakat desa dalam hal ini di Jawa, ${ }^{3}$ sebagaimana disebut di atas memiliki korelasi yang erat dengan

${ }^{2}$ M. Darori Amin, ed., Islam dan Kebudayaan Jawa (Yogyakarta: Gama Media, 2002), 66.

${ }^{3}$ Masyarakat Jawa, atau tepatnya suku bangsa Jawa secara antropologi budaya adalah orang-orang yang hidup dalam kesehariannnya menggunakan bahasa Jawa dengan berbagai dialeknya secara turun temurun yang bertempat 
falsafah hidup bangsa Indonesia yang dibangun dengan landasan Pancasila, yaitu sila ketiga "Persatuan dan kesatuan". Tidak akan pernah terwujud sebuah persatuan dalam satu kesatuan tanpa kerukunan yang terjalin. Nilai sosio-religius, jika bisa hidup rukun dan saling pengertian satu sama lain pastilah hidup akan menjadi sentosa, sejahtera dan persatuan akan terjalin. Selain itu masyarakat Jawa pada umumnya adalah masyarakat yang memiliki falsafah hidup yang berpusat pada konsep harmoni. Konsep hidup bermasyarakat ini memiliki dua landasan pokok yaitu, Pertama, menghindari konflik dan menjaga sifat hidup rukun seperti tercantum dalam peribahasa rukun agawe santoso crah agawe bubrah, yang artinya "kerukunan akan menjadi kuat, perselisihan hanya akan mendatangkan kehancuran". Kedua, sikap hidup ini dilandasi dengan sikap saling menghormati yang bertujuan pada terciptanya keselarasan hidup. Prinsip hidup masyarakat Jawa juga diungkapkan dalam ungkapan tata titi tentrem karta raharja yang berarti "tertata, cermat, tenteram dan sejahtera". Untuk mengontrol nilai itu manusia Jawa memiliki beberapa norma sosial yang merupakan kendali perilakunya dalam hidup bermasyarakat, yaitu rukun, tepa-slira, jujur, andhap asor, aja dumeh, tulung-tinulung, wani ngalah, wani wedi, wani isen, kepotangan budi dan lain-lain.

Salah satu dari sekian banyak masyarakat desa di Indonesia yang menjalankan dan menerapkan pluralisme agama adalah masyarakat Desa Banguntapan, Kecamatan Banguntapan, Kabupaten Bantul, Daerah Istimewa Yogyakarta. Masyarakat desa ini sangat manjemuk, tidak hanya dari agama yang mereka anut, tapi juga bermacam-macam organisasi keagamaan juga tumbuh subur. Di tengah-tengah desa ini, berdiri sebuah Pura yang cukup terkenal di Yogyakarta, yaitu Pura Jagatnata, tempat ibadah pemeluk Hindu. Pada sisi lain, di masyarakat desa ini juga tumbuh organisasi-organisasi Islam yang selama ini masuk kategori fundamentalis dan radikal seperti Lembaga Dakwah Islam Indonesia, Majelis Tafsir Al-Quran dan Majelis Mujahidin Indonesia. Di samping tiga organisasi Islam yang dikenal cukup luas ini, jelas terdapat organisasi Islam moderat seperti Nahdlatul 
Ulama dan Muhammadiyah juga berkembang pesat. Meskipun demikian, fenomena kerukunan beragama sangat dinamis, antar umat beragama bisa hidup berdampingan. Bahkan, jika ada orang yang mencoba mengusik kerukunan beragama, ia akan berhadapan dengan seluruh masyarakat desa yang terdiri dari umat Kristiani dan umat Islam serta pemeluk agama lainnya. Bagi mereka kehidupan harmoni lebih penting ketimbang bersitegang karena masalah agama yang bisa berujung ketidaknyamanan.

Penelitian ini pada hakekatnya ingin mengkaji kearifan lokal masyarakat desa dalam menjalankan kehidupan sosial yang religius melalui pola interaksi. Penelitian ini sangat menarik, karena pemahaman masyarakat desa tentang pluralisme agama tentu berbeda dengan pemahaman para akademisi. Pemahaman masyarakat desa tentang pluralisme agama akan menambah khazanah dan meneguhkan betapa masyarakat desa bukanlah masyarakat marginal yang bodoh dan tidak tahu apa-apa, sebaliknya mereka memiliki cara pandang yang berbeda namun bijaksana meskipun mereka tidak tahu perangkat-perangkat teori.

\section{Metode Penelitian}

Penelitian ini menggunakan metode kualitatif. Metode ini dipilih karena menekankan pada kedalaman nilai. Metode ini mencoba menjawab bagaimana pilihan tindakan untuk dimaknai dan diberi arti tertentu. Berbeda halnya dengan metode kuantitatif yang menekankan pengukuran dan analisis hubungan kausalitas antara variabel, bukan menekankan untuk melihat proses dan substansi terdalam suatu permasalahan. ${ }^{4}$

Tipe penelitian ini adalah deskriptif-kualitatif (descriptivequalitative research) yang menguraikan permasalahan secara deskriptif dengan melihat konteks permasalahan dan motif tindakan individu dalam suatu kolektivitas kemasyarakatan. Tipe penelitian deskriptif ini dipakai karena permasalahan yang melatarbelakanginya cukup kompleks sehingga diperlukan cara deskriptif untuk mengungkap realitas sosial yang ada agar tercapai inti terdalam dari tindakan dan pilihan masyarakat desa dalam menjalankan pluralisme agama. Namun demikian,

${ }^{4}$ Agus Salim, Teori dan paradigma penelitian sosial: (dari Denzin Guba dan penerapannya) (Yogyakarta: Tiara Wacana Yogya, 2001), 11. 
penelitian ini tetap memanfaatkan data-data statistik penerapan kerukunan antar umat beragama yang dihimpun dari data-data lapangan.

Jenis data dalam penelitian ini terbagi dua macam, yakni: 1) Data Primer, yaitu data-data lapangan diperoleh dan subyek penelitian atau responden langsung, yaitu masyarakat desa, tokoh agama, pejabat Desa dan Kelurahan. Adapun keseluruhan sampling yang menjadi sumber data menggunakan teknik purposive sampling atau penentuan sampel ditentukan oleh peneliti berdasarkan tujuan yang ingin dicapai dalam penelitian ini. ${ }^{5}$ ) Data Sekunder, yakni sumber data pustaka diperoleh dan literatur-literatur baik yang berbentuk buku, majalah, surat kabar, dan jurnal yang mempunyai keterkaitan langsung dengan fokus kajian penelitian ini. Selain tentu saja, literatur-literatur yang berisikan analisis pluralisme agama guna mendapatkan pertautan logis dengan data-data di lapangan.

Teknik pengumpulan data dilakukan dengan pengamatan, wawancara berpedoman (guided interview) dan wawancara mendalam (in-depht interview). Wawancara berpedoman dimaksudkan agar penggalian data dan informasi dapat terarah sekaligus memungkinkan untuk dilakukan pengembangan pertanyaan berdasarkan jawaban informan. Sedang wawancara mendalam akan dilakukan kepada para pihak terkait dan utamanya terhadap masyarakat desa dalam menjalankan kerukunan antar umat beragama. ${ }^{6}$

Selain itu teknik pengumpulan juga menggunakan observasi. Teknik observasi adalah teknik pengumpulan data dengan cara peneliti melakukan pengamatan secara langsung di lapangan. Pengamat disebut observer yang diamati disebut obyek observasi. Metode observasi merupakan metode pengumpul data yang dilakukan dengan cara mengamati dan mencatat secara sistematik gejala-gejala yang diselidiki. ${ }^{7}$ Observasi dilakukan

${ }^{5}$ M. Atho Mudzhar, Pendekatan studi Islam dalam teori dan praktek (Yogyakarta: Pustaka Pelajar, 1998), 70.

${ }^{6} \mathrm{H}$. Noeng Muhadjir, Metodologi penelitian kualitatif: pendekatan positivistik, rasionalistik, phenomenologik, dan realisme metaphistik, telaah studi teks dan penelitian agama (Yogyakarta, Indonesia: Rake Sarasin, 1996), 39.

${ }^{7}$ Arikunto Arikunto, Suhardjono, and Supardi, Penelitian tindakan kelas (Jakarta: Bumi Aksara, 2012), 88. 
menurut prosedur dan aturan tertentu sehingga dapat diulangi kembali oleh peneliti dan hasil observasi memberikan kemungkinan untuk ditafsirkan secara ilmiah.

Hasil wawancara atau informasi diharapkan antara lain berupa; faktor-faktor yang mendorong kerukunan antar umat beragama, motif-motif yang mendorong kerukunan antar umat beragama, dan usaha pemerintah dalam menyikapi fenomena ini. Wawancara juga akan dilakukan pada tokoh agama setempat. ${ }^{8}$

Teknik dokumentasi merupakan alat pengumpul data utama dalam mengumpul data untuk membuktikan hipotesis baik secara logis maupun rasional terhadap pendapat, teori hukum, yang berkaitan dengan penelitian geografis meliputi Kotamadya Yogyakarta yang berbatasan langsung secara geografis dengan Desa Banguntapan.

Penelitian ini mengambil lokasi di Desa Banguntapan, Kecamatan Banguntapan, Kabupaten Bantul, DI Yogyakarta, karena bila dibandingkan dengan desa lainnya paling tidak memiliki dua hal menarik. Pertama, Desa Banguntapan secara geografis berada di wilayah strategis, yaitu berbatasan langsung dengan Kota Yogyakarta, sehingga dinamika keragaman agama dan strata sosial masyarakat dapat dengan mudah dilihat di wilayah ini. Kedua, dalam pengamatan peneliti, Desa Banguntapan dijadikan lokasi penelitian dengan pertimbangan bahwa masyarakat setempat dikenal sangat plural dan dinamis, tetapi meraka mampu menciptakan harmoni dalam kehidupan dan toleransi serta bisa bekerjasama dalam berbagai bidang kehidupan.

Arah penelitian ini menggunakan analisis deskriptif yang bertujuan untuk menggambarkan keadaan dan status fenomena. Maka, setelah menemukan data-data kualitatif dari lapangan dengan tetap memperhatikan prinsip validitas dan objektifitas data, kemudian dilakukan analisis dengan instrumen analisis deduktif dan induktif.' Berbagai data yang bersifat primer dan sekunder itu akan menjadi bahan analisis dengan cara

${ }^{8}$ Lexy J Moleong, Metodologi penelitian kualitatif (Bandung: PT Remaja Rosdakarya, 2000), 15-21.

${ }^{9}$ Sutrisno Hadi, Metodologi research jilid 2 (Yogyakarta: Andi Offset, 2004), 36 . 
mendialektikkannya, sehingga tidak terjebak dalam analisis atau tafsir yang monolitis dan dapat mereduksi pendalaman suatu kajian.

\section{Hasil Penelitian}

\section{Selayang Pandang Desa Banguntapan}

Proses terbentuknya Desa Banguntapan Berdasarkan Maklumat Pemerintah Daerah Istimewa Yogyakarta tahun 1946 mengenai Pemerintah Kelurahan, maka 6 (enam) Kelurahan di wilayah ini yakni Kelurahan Pengawat Rejo, Kelurahan Wonocatur, Kelurahan Sorowajan, Kelurahan Katandan, Kelurahan Pringgolayan dan Kelurahan Pilahan digabung menjadi satu "Kelurahan yang Otonom" dengan nama Kelurahan Banguntapan, dengan Bapak Dirjo Sumarto sebagai lurah pertama Nama tersebut kemudian secara resmi ditetapkan berdasarkan Maklumat Pemerintah Daerah lstimewa Yogyakarta Nomor 5 tahun 1948 tentang perubahan daerah-daerah Kelurahan.

Dari Kelurahan-Kelurahan tersebut di atas, berdasar Undang Undang Rl Tahun 1947 Nomor: 17 tentang pembentukan Haminte Kota Yogyakarta, akhirnya dari wilayah Gedongkuning ke barat dan Gedongkuning ke selatan yang masuk menjadi Kelurahan Pilahan masuk wilayah Kota Yogyakarta sampai sekarang.

Menurut sejarah \pm pada tahun 1797 di wilayah ini pernah didirikan sebuah kerajaan oleh Sinuwun Banguntopo atau Sinuwun Hamengkubuwono ke II yang di beri nama Kerajaan Rejo Binangun atau Rejo Winangun. Setelah diadakan penggabungan kelurahan, nama Rejo Binangun atau Rejo Winangun dipakai sebagai nama kelurahan di wilayah Kota Madia Yogyakarta, sedangkan kelurahan yang masuk di wilayah Kabupaten Bantul di beri nama kelurahan Banguntapan, yang berasal dari kata "Banguntopo" sampai dengan sekarang.

Desa Banguntapan Kecamatan Banguntapan Kabupaten Bantul Provinsi DI Yogyakarta adalah salah satu desa yang yang mempunyai corak mayarakat majemuk/heterogen, tidak seperti halnya sebuah desa yang penduduknya berciri mata pencaharian pertanian dan homogen karena Desa Banguntapan lebih berciri 
pada masyarakat kota. Hal ini disebabkan karena Desa Banguntapan memang merupakan kota satelit yang berbatasan langsung dengan Kota Yogyakarta yaitu Ibu Kota Provinsi Daerah Istimewa Yogyakarta. Luas wilayah Desa Banguntapan yaitu: 1465, $32 \mathrm{H}$ yang terdiri dari :

Tabel 1: Luas Wilayah Desa Banguntapan

\begin{tabular}{lll}
\hline $\mathbf{N o}$ & Jenis Tanah & Luas \\
\hline $\mathbf{1}$ & Tanah Sawah & $184,35 \mathrm{H}$ \\
\hline $\mathbf{2}$ & Tanah Tegalan & $7,05 \mathrm{H}$ \\
\hline $\mathbf{3}$ & Tanah Pekarangan & $598,93 \mathrm{H}$ \\
\hline $\mathbf{4}$ & Tanah untuk Saluran & $8,19 \mathrm{H}$ \\
\hline $\mathbf{5}$ & Tanah untuk Jalan & $11,80 \mathrm{H}$ \\
\hline $\mathbf{6}$ & Tanah Lain-lain & $655 \mathrm{H}$ \\
\hline & Jumlah & $1465,32 \mathrm{H}$ \\
\hline
\end{tabular}

Batas Wilayah Desa Banguntapan

1. Sebelah Utara : Desa Catur Tunggal Kab. Sleman

2. Sebelah Timur : Desa Baturetno Kab. Bantul

3. Sebelah Selatan : Desa Wirokerten Kab. Bantul

4. Sebelah Barat : Kelurahan Rejowinangun Kodya Yogyakarta

Adapun jumlah penduduk Desa Banguntapan berdasarkan jenis kelamin pada tahun 2016 yaitu:

Tabel 2: Jumlah Penduduk Berdasarkan Jenis Kelamin

\begin{tabular}{lll}
\hline No & Jenis Kelamin & Jumlah \\
\hline $\mathbf{1}$ & Laki-laki & 21.890 Jiwa \\
\hline $\mathbf{2}$ & Perempuan & 21.827 Jiwa \\
\hline & Jumlah & 43.717 Jiwa \\
\hline
\end{tabular}

Tabel 3: Daftar Pemeluk Agama

\begin{tabular}{lll}
\hline No & Pemeluk Agama & Jumlah \\
\hline $\mathbf{1}$ & Islam & 34.955 \\
\hline $\mathbf{2}$ & Kristen & 2.642 \\
\hline $\mathbf{3}$ & Katholik & 3.498 \\
\hline $\mathbf{4}$ & Hindu & 1.748 \\
\hline
\end{tabular}




\begin{tabular}{lll}
\hline $\mathbf{5}$ & Budha & 874 \\
\hline $\mathbf{6}$ & Kong Huchu & - \\
\hline & Jumlah & 43.717 \\
\hline
\end{tabular}

Tabel 4: Tempat Ibadah

\begin{tabular}{lll}
\hline No & Nama Tempat Ibadah & Jumlah \\
\hline $\mathbf{1}$ & Masjid & 58 \\
\hline $\mathbf{2}$ & Musala & 30 \\
\hline $\mathbf{3}$ & Gereja & 9 \\
$\mathbf{4}$ & Pura & 2 \\
\hline $\mathbf{5}$ & Kelenteng & - \\
\hline & Jumlah & 99 \\
\hline
\end{tabular}

Tabel 5: Tingkat pendidikan masyarakat Desa Banguntapan

\begin{tabular}{lll}
\hline No & Tingkat Pendidikan & Jumlah \\
\hline $\mathbf{1}$ & Belum sekolah & 6.557 \\
\hline $\mathbf{2}$ & PAUD dan TK & 3.400 \\
\hline $\mathbf{3}$ & SD/MI sederajat & 5.465 \\
\hline $\mathbf{4}$ & SMP/MTS sederajat & 4.665 \\
\hline $\mathbf{5}$ & SMA/MA sederajat & 11.919 \\
\hline $\mathbf{6}$ & Perguruan Tinggi & 7.743 \\
\hline & Jumlah & 39.749 \\
\hline
\end{tabular}

Organisasi Pemerintah Desa Banguntapan

- Lurah Desa : Basirudin

- Carik Desa/Sekdes $\quad$ : Puthut Damarjati, SE.

- Kasi Pemerintahan : H. Wardjono, BA.

- Kasi Kesejahteraan : Sutikmantoro, BA

- Kasi Pelayanan : Sudarmaji

- Kaur Keuangan : Drs. Endro Suryono

- Kaur Perencanaa : Fitriyadi Wahyono

- Kaur TU dan Umum : Suharjono, SE. 
Nilai Sosio-Religius Masyarakat Desa: Studi Interaksi Antarumat Beragama di Yogyakarta

Dibantu oleh 10 Staf desa dan 2 penjaga malam serta petugas dapur/kebersihan.

Tabel 6: Pedukuhan Desa Banguntapan

\begin{tabular}{lll}
\hline No & Nama Pedukuhan & Nama Dukuh \\
\hline $\mathbf{1}$ & Modalan & Joko Danang, SH \\
\hline $\mathbf{2}$ & Pringgolayan & $\begin{array}{l}\text { Bambang Wisnu } \\
\text { Kardi }\end{array}$ \\
\hline $\mathbf{3}$ & Plumbon & Aris Purnomo \\
\hline $\mathbf{4}$ & Sorowajan & Sularto, Bsc \\
\hline $\mathbf{5}$ & Karangbendo & Siti sujaroh, SE \\
\hline $\mathbf{6}$ & Karang Jambe & Herguswanto \\
\hline $\mathbf{7}$ & Wonocatur & Bachrun \\
\hline $\mathbf{8}$ & Jumblangan & $\begin{array}{l}\text { Sigit } \\
\text { herjuno, ST }\end{array}$ \\
\hline $\mathbf{9}$ & Jaranan & Kasmijo \\
\hline $\mathbf{1 0}$ & Tegal Tandan & Mardiyono \\
\hline
\end{tabular}

Kelembagaan Desa

A. Badan Permusyawaratan Desa (BPD), yang merupakan unsur penyelenggara Pemerintahan Desa. Bersama dengan Lurah Desa membuat Peraturan Desa, menetapkan APBdes, dan mengawasi pelaksanaan Peraturan Desa. Struktur BPD terdiri dari 9 Anggota:

- Ketua : H. Sabardi

- Wakil Ketua : Sarjimin B.Sc.

- Sekretaris : Slamet Pribadi

Terdiri dari 6 anggota BPD dan dibantu oleh 1 orang Kepala Tata Usaha BPD yang merupakan unsur pamong desa

B. Lembaga Pemberdayaan Masyarakat Desa (LPMD)

- Ketua : Ir. Hadi Purwoko

- Sekretaris : Kuat Diyono

- Bendahara : Mumpuni Ratri

Sedangkan Pemberdayaan Kesejahteraan Keluarga (PKK) terdiri dari:

- Ketua : Ibu Subardilah

- Sekretaris : Ibu Yekti Lestari 


\section{- Bendahara : Ibu Musri ${ }^{10}$}

\section{Pluralitas sebuah keniscayaan}

Pluralitas adalah sebuah keniscayaan dalam kehidupan ini. Tuhan Yang Maha Kuasa menciptakan alam ini di atas sunah pluralitas dalam sebuah kerangka kesatuan. Isu pluralitas adalah setua usia manusia dan selamanya akan ada selama kehidupan belum berakhir, hanya saja bisa terus menerus berubah, sesuai perkembangan zaman. Pluralitas pada hakikatnya merupakan realitas kehidupan itu sendiri, yang tidak bisa dihindari dan ditolak. Karena pluralitas merupakan sunatullah, maka eksistensi atau keberadaannya harus diakui oleh setiap manusia sebagai sebuah fakta empiris. Namun pengakuan ini dalam tataran realitas belum sepenuhnya lengkap dan final seiring dengan pengakuan secara teoritik dan kendala-kendala masih sering dijumpai dilapangan. Dalam kehidupan sehari-hari sebelum dicampuri dengan kepentingan ideologis, ekonomis, sosialpolitik, agama dan lainnya, manusia menjalani kehidupan yang bersifat pluralitas secara ilmiah, tanpa begitu banyak mempertimbangkan sampai pada tingkat "benar tidaknya" realitas pluralitas yang menyatu dalam kehidupan sehari-hari. Baru ketika manusia dengan berbagai kepentingannya (organisasi, politik, agama, budaya dan lainnya) mulai mengangkat isu pluralitas pada puncak kesadaran mereka dan menjadikannya sebagai pusat perhatian. Maka pluralitas yang semula bersifat wajar, alamiah berubah menjadi hal yang sangat penting.

Agama sebagai sebuah tatanan nilai, sebenarnya membutuhkan medium budaya agar keberadaannya membumi dalam kehidupan umat pemeluknya dan ia diharapkan menjadi institusi bagi pengalaman iman kepada Sang Khalik. Di sini agama menawarkan agenda penyelamatan manusia secara universal, namun disisi yang lain agama sebagai sebuah kesadaran makna dan legitimasi tindakan bagi pemeluknya, dalam interaksi sosialnya banyak mengalami perbedaan hermeneutik sehingga tidak pelak memunculkan konflik. Pluralitas agama disatu sisi, dan heterogenitas realitas sosial pemeluknya disisi yang lain, tidak

${ }^{10}$ Sumber: Data dari Desa Banguntapan 
jarang menimbulkan benturan-benturan dalam tataran tafsir atau dogma agama maupun dalam tataran aksi. ${ }^{11}$

Sudah saatnya bagi para da'i Islam untuk mengetahui bahwa mereka tidak dituntut untuk mengislamkan orang-orang yang beragama selain Islam, mereka tidak berhak mengklaim bahwa selain orang Islam akan masuk neraka, karena kunci-kunci surga bukan di tangan mereka. Para da'i hanya bertugas mengenalkan Islam kepada mereka, urusan konversi agama tidak hanya menyangkut iman dan teori, ini hanya menyangkut hubungan sosial dan konsekuensi-konsekuensi selanjutnya, hidayah hanya datang dari Allah.

Dengan pengetahuannya manusia memiliki free will (kehendak bebas) untuk berbuat yang terbaik berdasarkan pertimbangan akal sehatnya. Pemikiran seperti ini walaupun tidak dipelajari atau diketahui oleh semua lapisan masyarakat Banguntapan, tetapi memahaminya melaui konsep Hak Asasi Manusia yang manusia dalam konsep tersebut bebas memeluk agama atau jalan hidup yang ditempuhnya sesuai dengan pilihannya. Sehingga ketika ada orang yang berbeda keyakinan dengan mereka, itu tidak dipersoalkan, karena dengan jelas mereka mengatakan bahwa itu urusan pribadi dan hak asasi orang lain yang harus dihormati, bukan urusan mereka untuk mencampurinya. Hal ini sesuai dengan peribahasa rukun agawe santoso crah agawe bubrah, yang artinya "kerukunan akan menjadi kuat, perselisihan hanya akan mendatangkan kehancuran".

Pada kerangka inilah menurut peneliti, masyarakat Banguntapan memaknai pluralitas secara sederhana namun dengan sikap penuh kesehajaan. Walaupun tampaknya sederhana, tetapi mereka betul-betul menghormatinya. Bahkan dalam mengimplementasikan makna pluralitas tersebut tidak jarang ditemui dalam sebuah keluarga menganut agama yang berbeda. Misalnya ada keluarga beda agama akibat perkawinan, memiliki menantu yang agamanya Islam sedangkan keluarga tersebut beragama Kristen. Bagi sebagian masyarakat Banguntapan tidak ada masalah hal seperti itu, sejauh anak dan menantunya menjadi penganut agama yang baik kalau memang

${ }^{11}\{$ Citation\} 
sudah menjadi pilihannya, hendaklah menjalankan agama dengan sungguh-sungguh karena agama itu mengajarkan nilai-nilai kebaikan bagi manusia.

\section{Nilai sosio-religius}

Dalam Kamus Sosiologi, Soerjono Soekanto ${ }^{12}$ disebutkan bahwa nilai (value) adalah konsepsi-konsepsi abstrak di dalam diri manusia, mengenai apa yang dianggap baik dan apa yang dianggap buruk. Koentjaraningrat ${ }^{13}$ menjelaskan nilai sebagai nilai budaya yang terdiri dari konsepsi yang hidup dalam alam pikiran sebahagian besar warga masyarakat mengenai hal-hal yang mereka anggap amat mulia. Sistem nilai yang ada dalam suatu masyarakat dijadikan orientasi dan rujukan dalam bertindak. Oleh karena itu, nilai budaya yang dimiliki seseorang mempengaruhinya dalam menentukan alternatif, cara-cara, alat-alat, dan tujuan-tujuan pembuatan yang tersedia.

Nilai sosial dalam kehidupan masyarakat Banguntapan masih terjaga dengan baik. Mereka beranggapan nilai sosial itu sangat agung dan perlu dijunjung tinggi dalam rangka mewujudkan masyarakat yang damai sejahtera. Sistem nilai itu memang dijadikan sebagai tujuan hidup yang harus diwujudkan dalam kehidupan bermasyarakat dengan menghargai sesama atau orang yang berbeda suku, agama dan budaya. Sehingga masyarakat Banguntapan menghindari pertikaian dan permusuhan yang mengakibatkan terjadinya bentrokan fisik.

Menanamkan nilai sosial yang sangat kuat ini ternyata mampu meredam terjadinya gesekan-gesekan yang bisa saja muncul. Beberapa kasus misalnya ijin pendirian rumah ibadah yang biasanya cukup rumit dan sensitif. Tapi karena masyarakat Banguntapan sangat menjunjung tinggi nilai-nilai kemanusiaan, masalah tersebut selalu diupayakan diselesaikan dengan cara

\footnotetext{
${ }^{12}$ Surjono Sukanto, Kamus sosiologi (Jakarta: PT Raja Grafindo Persada, 1993).

${ }^{13}$ Koentjaraningrat, Sejarah teori antropologi (Jakarta: Penerbit Universitas Indonesia, 1987), 85.
} 
dialog. Dengan dialog persoalan-persoalan yang ada dibicarakan dengan kepala dingin dan menghindari merasa paling benar sendiri. Budaya dialog ini selalu dijaga, bahkan masyarakat sudah paham betul bahwa tidak ada masalah yang tidak bisa diselesaikan dengan berdialog.

Menurut Blumer tindakan manusia bukan disebabkan oleh beberapa "kekuatan luar" (seperti yang dimaksudkan oleh kaum fungsionalis struktural) tidak pula disebabkan oleh "kekuatan dalam"(seperti yang dinyatakan oleh kaum reduksionis-psikologis) Blumer, menyanggah individu bukan dikelilingi oleh lingkungan obyek-obyek pontensional yang mempermainkannya dan membentuk perilakunya. Gambaran yang benar ialah dia membentuk obyek-obyek itu, misalnya berpakaian atau mempersiapkan diri untuk karir profesionalindividu sebenarnya sedang merancang obyek-obyek yang berbeda, memberinya arti, menilai kesesuaiannya dengan tindakan, dan mengambil keputusan berdasarkan penilai tersebut. Inilah yang dimaksud dengan penafsiran atau bertindak berdasarkan simbol-simbol. ${ }^{14}$

Pemikiran Nurcholis Madjid sangat tepat untuk membaca akulturasi budaya di Banguntapan, hal ini bisa dilihat bahwa walau laju pendatang yang masuk di Banguntapan tinggi dan kuatnya arus modernitas yang melanda kehidupan masyarakat, ternyata akulturasi budaya dalam nilai-nilai sosial masyarakat yang ada berjalan berkelindan tanpa menghilangkan identitas masyarakat Banguntapan, pada umumnya masyarakat Jawa yang sangat respek budaya leluhurnya namun dapat menerima budaya luar. Sehingga benar bila jarang terjadi gesekan dan pertikaian. Bila potensi muncul biasanya mereka bisa menyelesaikan dengan cara dialog, musyawarah untuk mufakat, sehingga benih-benih pertikaian bisa diminimalisir secara maksimal.

Bila melihatnya dalam bentuk proses sosial dissosiatif, maka menjadi tampak bahwa:

a. Persaingan (competition), merupakan suatu proses sosial, dimana individu atau kelompok-kelompok manusia yang

${ }^{14}$ Herbert Blumer, Symbolic Interactionism: Perspective and Method (Berkeley: Univ. of California Press, 2009). 
bersaing mencari keuntungan melalui bidang-bidang kehidupan yang pada suatu masa tertentu, dengan cara mempertajam prasangka yang telah ada tanpa mempergunakan ancaman atau kekerasan.

b. Kontravensi (contravention), merupakan suatu bentuk proses sosial yang berada antara persaingan dan pertentangan atau pertikaian. Kontravensi terutama ditandai sengan gejalagejala adanya ketidakpastian mengenai diri seseorang atau suatu rencana dan perasaan tidak suka yang disembunyikan, kebencian, atau keragu-raguan terhadap kepribadian seseorang.

c. Pertentangan (pertikaian atau konflik), merupakan proses sosial dimana individu atau kelompok berusaha untuk memenuhi tujuannya dengan jalan menantang pihak lawan yang disertai dengan ancaman dan atau kekerasan. Sebabsebab terjadinya konflik antara lain, perbedaan antar individu, perbedaan kebudayaan, perbedaan kepentingan, dan perubahan sosial. ${ }^{15}$

Dalam suatu masyarakat yang komunal merupakan sebuah keniscayaan adanya keragaman ataupun heterogenitas, hal itu merupakan hukum alam yang tidak bisa ditolak. Karenanya perlu sikap arif dan bijaksana untuk menghadapi itu semua.

Bahkan akhir-akhir ini dengan kemajuan sains dan teknologi yang dicapai manusia, menjadikan nilai-nilai sosial manusia mulai terkikis. Hal ini dapat dilihat pada konteks pekerjaan manusia yang menghendaki manusia bekerja menghabiskan sebagian besar waktunya untuk berinteraksi dengan pekerjaannya sehingga menghilangkan sebagian waktunya untuk bergaul dan berinteraksi sosial dengan lingkungan sosial budayanya. Apalagi dunia maya mulai ramai dengan hadirnya "facebook" yang merupakan jejaring sosial yang semakin memarjinalkan manusia dengan lingkungan sosialnya yang nyata, dimana terjadi saling bertukar informasi dan pergaulan yang semu. Hal ini menjadikan nilai-nilai sosial manusia semakin terpinggirkan.

${ }^{15}$ Soerjono Soekanto, Sosiologi: suatu pengantar (Jakarta: RajaGrafindo Persada, 2007), 68. 
Padahal pendidikan pada dasarnya adalah upaya manusia dan hasil budaya terbaik yang mampu disediakan setiap generasi manusia untuk kepentingan generasi berikutnya agar melanjutkan kehidupan dan cara hidupnya dalam konteks sosial budaya yang lebih baik. Oleh karena itu, setiap masyarakat pluralistik di zaman modern senantiasa menyiapkan warganya yang terpilih sebagai pendidik bagi kepentingan kelanjutan pendidikan dan kehidupan dari masyarakat bersangkutan. Pada sisi itulah diperlukan pendidikan, yang melampaui tata aturan di dalam keluarga namun tidak menghilangkan nilai-nilai sosial budaya yang terbanguan dalam lingkungan keluarga, lingkungan masyarakat dan lingkungan sosial yang lebih besar untuk meningkatkan harkat dan kepribadian individu agar menjadi manusia yang lebih cerdas dan mampu berada di tengah-tengah pergaulan masyarakatnya.

Dalam konteks ini, maka dapat dikatakan bahwa persoalan pendidikan nilai dalam kehidupan sosial masyarakat merupakan suatu persoalan yang kompleks karena melibatkan berbagai komponen. Karena pendidikan melibatkan berbagai unsur terkait dan komponen di dalamnya, maka beragam masalahpun sering bermunculan. Untuk itu diperlukan kondisi yang matang dan dinamis serta kesiapan pelaku pendidikan agar beragam masalah itu dapat disikapi secara arif dan bijaksana.

Nilai sosial-religius dalam pola interakasi antar umat beragama di Desa Banguntapan sangat berpengaruh dalam kehidupan yang plural. Ternyata dengan mengedepankan nilai sosial-religius, interaksi dalam kehidupan umat beragama dapat menjadi harmonis. Karena nilai-nilai tersebut menjadi pegangan oleh masyarakat dalam menjalani kehidupannya. Sehingga ada upaya untuk memelihara nilai tersebut.

\section{Interaksi Antarumat Beragama di Desa Banguntapan}

Teori interaksi sosial sesuai bila digunakan untuk melihat bahwa ada hubungan timbal balik antara individu dengan individu, kelompok dengan kelompok, individu dengan kelompok atau sebaliknya. Dengan adanya nilai dan norma yang berlaku sosial dapat dilakukan dengan baik. Jika tidak adanya kesadaran masing-masing antar individu dengan individu atau individu dengan kelompok, maka proses sosial itu tidak dapat 
berjalan baik dengan yang diharapkan.dalam kehidupan seharihari tentunya seseorang tidak lepas dengan berinteraksi atau bertukar pikiran. Menurut Soerjono Soekamto di dalam pengantar sosiologi, interaksi sosial merupakan kunci semua kehidupan sosial. Dengan tidak adanya komunikasi atau interaksi antar satu sama lain maka tidak ada kehidupan bersama. ${ }^{16}$

Interakasi sosial merupakan syarat utama terjadinya aktivitas-aktivitas sosial, dalam pengertiannya sendiri interaksi sosial merupakan hubungan-hubungan sosial yang dinamis yang menyangkut hubungan antara orang-perorang, antara kelompok manusia, maupun antara orang perorangan dengan kelompok manusia. Di dalam interaksi harus ada yang dinamakan dengan komunikasi dan kontak sosial. ${ }^{17}$ Bentuk interaksi dibedakan menjadi dua yaitu asosiatif dan disosiatif.

Menurut peneliti perlu ada upaya-upaya yang perlu dilakukan untuk memelihara pluralisme agama di Banguntapan, seperti:

a. Perlu adanya kampanye kesadaran dalam masyarakat Desa Banguntapan yang memiliki karakter yang berbeda dari pluralisme yang juga terdapat dalam masyarakat lain mulai dari level paling bawah, seperti keluarga.

b. Kesadaran umat beragama yang sehat akan mampu melihat dengan jernih sisi kebenaran yang terdapat dalam agama lain karena semua agama punya nilai-nilai kebenaran yang bersifat universal, tidak fanatisme agama secara berlebihan dan selalu membuka diri dengan orang lain walaupun berbeda agama dan keyakinan.

c. Menggalakkan dialog antarumat beragama. Salah satu faktor utama penyebab terjadinya konflik keagamaan adalah adanya paradigma keberagamaan masyarakat yang masih eksklusif (tertutup). Pemahaman keberagamaan ini tidak bisa dipandang sebelah mata karena pemahaman ini dapat membentuk pribadi yang antipati terhadap pemeluk agama

${ }^{16}$ Soekanto, Sosiologi.

${ }^{17}$ Hasan Sazali, "Komunikasi Pembangunan Agama Dalam Membangun Toleransi Agama (Analisis Sistem Dan Aktor)," Khazanah: Jurnal Studi Islam Dan Humaniora 13, no. 2 (April 25, 2016): 209, https://doi.org/10.18592/khazanah.v13i2.767. 
lainnya. Pribadi yang tertutup dan menutup ruang dialog dengan pemeluk agama lainnya.

d. Membangun persaudaraan antar umat beragama seperti adanya Forum Komunikasi Umat Beragama adalah kebutuhan yang urgen untuk diperjuangkan sepanjang waktu. Persaudaraan antarsesama umat beragama itu hanya dapat dibangun melalui dialog yang serius yang diadasarkan pada ajaran-ajaran normatif masing-masing dan komonikasi yang intens, dengan dialog dan komunikasi tersebut akan terbangun rasa persaudaraan yang sejati.

e. Dialog antarumat beragama mempersiapkan diri untuk melakukan diskusi dengan umat agama lain yang berbeda pandangan tentang kenyataan hidup. Dialog tersebut dimaksudkan untuk saling mengenal, saling pengertian, dan saling menimba pengetahuan baru tentang agama mitra dialog. Dengan dialog akan memperkaya wawasan kedua belah pihak dalam rangka mencari persamaan-persamaan yang dapat dijadikan landasan hidup rukun dalam suatu masyarakat, yaitu toleransi dan pluralisme. Agama Islam sejak semula telah menganjurkan dialog dengan umat lain, terutama dengan umat Kristen dan Yahudi yang di dalam alQur'an disebut dengan ungkapan abl al-Kitâb (yang memiliki kitab suci).

f. Menggali semangat pluralisme dalam masyarakat dengan bijak. Dalam menggali semangat pluralisme kita harus menjaga sikap sikap toleran kepada umat agama lain. Karena hal ini merupakan landasan agar pluralisme dalam beragama dapat tercipta dengan baik dan antarumat beragama dapat bermasyarakat dengan baik tanpa saling mengucilkan atau menjelek jelekan agama lain.

g. Saling menjaga tempat-tempat peribadatan. Dalam hal ini kita harus menjaga tempat peribadatan umat beragama, baik dalam hal kenyamanan maupun keamanan. Karena jika umat agama lan dapat menjalankan ritual keagamaannya dengan tentram maka hal itu pula yang akan terjadi pada hubungan antar umat beragama.

h. Saling meniadakan dalam bentuk konflik antar agama. Hal ini lebih merujuk kepada kesadaran kelompok agama untuk 
tidak encampuri urusan internal umat beragama lainnya, karena hal ini merupakan sebuah privasi bagi suatu kelompok umat beragama yang sedang memiliki konflik intern.

i. Saling menjaga relasi antar umat beragama. Agama secara normatif-doktriner selalu mengajarkan kebaikan, cinta kasih dan kerukunan. Dalam hal ini agama mengajarkan untuk menghormati umat agama lain, dan hal ini sangat ditekankan oleh semua agama terlebih lagi agama Islam.

Erving Goffman juga menyampaikan konsep impression management untuk menunjukkan usaha individu dalam menampilkan kesan tertentu pada orang lain. Konsep expression untuk individu yang membuat pernyataan dalam interaksi. Konsep ini terbagi atas expression given untuk pernyataan yang diberikan dan expression given off untuk pernyataan yang terlepas. Serta konsep impression untuk individu lain yang memperoleh kesan dalam interaksi. ${ }^{18}$

Masyarakat Desa Banguntapan senantiasa melakukan hubungan dan pengaruh timbal balik dengan masyarakat yang lain dalam rangka memenuhi kebutuhan dan mempertahankan kehidupannya. Bahkan, mereka beranggapan mempunyai arti jika ada manusia yang lain tempat ia berinteraksi. Interaksi sosial bisa didefinisikan sebagai hubungan dan pengaruh timbal balik antara individu dengan individu, individu dengan kelompok individu yang lainnya. Interaksi sosial mereka pahami merupakan bentuk dari dinamika sosial budaya yang ada di dalam kehidupan bermasyarakat. Dengan demikian, dengan interaksi sosial akan memungkinkan terjadinya perubahan-perubahan di dalam masyarakat yang akan membentuk hal-hal yang baru yang membuat dinamika masyarakat menjadi hidup. Perubahanperubahan ini akan terjadi sambung-menyambung dari generasi yang satu ke generasi berikutnya sepanjang zaman.

Bentuk hubungan sosial atau interaksi sosial dalam masyarakat Desa Banguntapan yang berbeda latar belakang kebudayaan tersebut dapat berupa kerja sama, persaingan, pertikaian dan akomodasi. Bentuk hubungan sosial tersebut selain dapat menimbulkan ketegangan atau konflik sosial diantara

${ }^{18}$ Basrowi and Sukidin, Metode Penelitian Kualitatif, Penelitian (Surabaya: Penerbit Insan Cendekia, 2002), 103. 
masyarakat juga dapat memunculkan sikap solidaritas diantara masyarakat majemuk, berupa suatu bentuk kerjasama pada masyarakat yang meliputi aktivitas gotong royong, tolong menolong dan musyawarah. Selain rasa kepatuhan yang didasarkan kepada perasaan moral, masyarakat juga mengenal seperangkat nilai yang intinya memupuk rasa solidaritas atau disebut nilai yang mempersatukan (assosiatif) yang mempunyai butir-butir positif yaitu persaudaraan, kekeluargaan, kerukunan dan kegotong-royongan inilah yang menjadi pegangan masyarakat Desa Banguntapan selama ini.

\section{Penutup}

Dari paparan hasil penelitian di atas, dapat disimpulkan beberapa hal sebagai berikut:

Pertama, kondisi keberagamaan di Desa Banguntapan berjalan dengan baik walaupun ada potensi untuk terjadinya gesekan-gesekan tapi sejauh ini masih bisa diminimalisir dengan semangat kebersamaan sekalipun masyarakatnya terdapat keberagaman.

Kedua, masyarakat Desa Banguntapan memang heterogen, hampir semua suku bangsa Indonesia dari Sabang sampai Merauke ada di sini. Masyarakat asli Banguntapan yang dalam hal ini orang Jawa mempunyai sikap inklusif terhadap pendatang dari luar Banguntapan (luar Yogyakarta pada umumnya). Masyarakat Jawa dikenal terbuka dengan kaum pendatang darimana saja, yang penting bisa beradaptasi dan menghargai tradisi masyarakat Jawa yang penuh dengan budaya tatakrama.

Ketiga, Nilai sosio-religius dalam pola interaksi antarumat beragama masyarakat Desa Banguntapan senantiasa dalam konteks hubungan dan pengaruh timbal balik dengan masyarakat yang lain dalam rangka memenuhi kebutuhan dan mempertahankan kehidupannya. Bahkan, mereka beranggapan mempunyai arti jika ada manusia yang lain tempat ia berinteraksi. Interaksi sosial bisa didefinisikan sebagai hubungan dan pengaruh timbal balik antara individu dengan individu, individu dengan kelompok individu yang lainnya. Interaksi sosial mereka 
pahami merupakan bentuk dari dinamika sosial budaya yang ada di dalam kehidupan bermasyarakat.

\section{DAFTAR PUSTAKA}

Amin, M. Darori, ed. Islam dan Kebudayaan Jawa. Yogyakarta: Gama Media, 2002.

Arikunto, Arikunto, Suhardjono, and Supardi. Penelitian tindakan kelas. Jakarta: Bumi Aksara, 2012. http://opac.library.um.ac.id/oaipmh/../index.php?s_da ta $=$ bp_buku\&s_field $=0 \& \bmod =$ b\&cat $=3 \& i d=43265$.

Basrowi, and Sukidin. Metode Penelitian Kualitatif, Penelitian. Surabaya: Penerbit Insan Cendekia, 2002.

Blumer, Herbert. Symbolic Interactionism: Perspective and Method. Berkeley: Univ. of California Press, 2009.

Hadi, Sutrisno. Metodologi research jilid 2. Yogyakarta: Andi Offset, 2004.

Kodiran. Kebudayaan Jawa Dalam Manusia Dan Kebudayaan Di Indonesia. Jakarta: Jembatan, 1976.

Koentjaraningrat. Sejarah teori antropologi. Jakarta: Penerbit Universitas Indonesia, 1987.

Moleong, Lexy J. Metodologi penelitian kualitatif. Bandung: PT Remaja Rosdakarya, 2000.

Mudzhar, M. Atho. Pendekatan studi Islam dalam teori dan praktek. Yogyakarta: Pustaka Pelajar, 1998. http://books.google.com/books?id=jwDkAAAAMAA $\mathrm{J}$.

Muhadjir, H. Noeng. Metodologi penelitian kualitatif: pendekatan positivistik, rasionalistik, phenomenologik, dan realisme metaphistik, telaah studi teks dan penelitian agama. Yogyakarta, Indonesia: Rake Sarasin, 1996.

Noertjahyo, J. A. Dari ladang sampai kabinet: menggugat nasib petani. Jakarta: Penerbit Buku Kompas, 2005.

Salim, Agus. Teori dan paradigma penelitian sosial: (dari Denzin Guba dan penerapannya). Yogyakarta: Tiara Wacana Yogya, 2001. 
Nilai Sosio-Religius Masyarakat Desa: Studi Interaksi Antarumat Beragama di Yogyakarta

Sazali, Hasan. "Komunikasi Pembangunan Agama Dalam Membangun Toleransi Agama (Analisis Sistem Dan Aktor)." Khazanah: Jurnal Studi Islam Dan Humaniora 13, no. 2 (April 25, 2016): 209. https://doi.org/10.18592/khazanah.v13i2.767.

Soekanto, Soerjono. Sosiologi: suatu pengantar. Jakarta: RajaGrafindo Persada, 2007.

Sukanto, Surjono. Kamus sosiologi. Jakarta: PT Raja Grafindo Persada, 1993. 